Acta Universitatis Nicolai Copernici • Pedagogika XXXI/2015

Nauki Humanistyczno-Społeczne • Zeszyt 426

DOI: http://dx.doi.org/10.12775/AUNC_PED.2015.007

Karolina Goede

Katedra Aksjologii Pedagogicznej i Metodologii Badań, Uniwersytet Kazimierza Wielkiego w Bydgoszczy

\title{
KOMPETENCJE MORALNE \\ JAKO KLUCZOWY ELEMENT W RELACJI WOLNOŚCI I ODPOWIEDZIALNOŚCI \\ ZA SLOWA W PROBACJI
}

Drobacja jest szczególnym obszarem działań pedagogicznych, gdzie 1 relacja wolności i odpowiedzialności za słowo nabiera podwójnego znaczenia. Faktem jest bowiem, iż osobom poddanym probacji już w okresie próby zostaje zawężona wolność osobista. Ograniczenia te dotyczą zarówno tak podstawowej sfery życia jak konieczność uzyskiwania zgody sądu na zmianę miejsca stałego pobytu ${ }^{1}$, jak również konieczności udzielania wyjaśnień i informacji kuratorowi sądowemu dotyczących osobistych sfer, jak relacje rodzinne, sytuacja materialna, zatrudnienie, uzależnienia bądź plany na przyszłość. Tak zawężona wolność osobista skazanych determinuje specyficzną przestrzeń relacji probacyjnej, która naznaczona jest formalną asymetrią. Jej podłoże stanowią wskazane ograniczenia wolności osobistej, ale również kierunek procesu resocjalizacji wytyczony przez cel, jak i forma dozoru

1 Art. 169 § 3 k.k.w. - Ustawa z dnia 6 czerwca 1997 - Kodeks karny wykonawczy - Dz. U. 1997 Nr 90 poz. 557. 
będąca pochodną sankcji karnej. Asymetria relacji probacyjnej implikuje konieczność zachowania rozwagi i odpowiedzialności za słowo ze strony kuratora sądowego. Roztropność i dalekowzroczność w komunikacji z dozorowanym stanowi niezbędny komponent sprzyjający nawiązaniu więzi interpersonalnej, stanowiącej pryncypium wszelkich działań resocjalizacyjnych. Bezrefleksyjne stwarzanie sytuacji ingerujących w już zawężoną sankcjami wolność osobistą skazanych ogranicza działalność probacyjną do funkcji kontrolnej. Pozbawiając ją tym samym szerokiego spectrum wartościowych oddziaływań i wpływów wynikających z autentycznej relacji interpersonalnej. Nie wszystkie ograniczenia wolności mają jednak wydźwięk pejoratywny. Probacja bowiem, jako alternatywa izolacji, jest swoistą szansą dla skazanego na readaptację w środowisku jego życia na określonych przez sąd warunkach. Brak nałożonych ograniczeń pozbawiałby karę jej podstawowych funkcji. O ile sankcje wynikające z wyroku i samego dozoru ograniczają głównie przestrzeń zewnętrznej wolności i pełnią postulowaną funkcję profilaktyczną, diagnostyczną oraz kontrolną, o tyle sama działalność wychowawczo-resocjalizacyjna kuratora sądowego może ingerować w sferę wolności wewnętrznej, jak tożsamość skazanego ${ }^{2}$. Działalność probacyjna w tym obszarze bowiem sprowadza się zarówno do zmiany relacji między skazanym i środowiskiem respektującym normy prawne i moralne, ale i do zmiany samej sfery aksjologicznej podopiecznego. Skazanie człowieka prawomocnym wyrokiem sądowym stanowi bowiem niezaprzeczalny fakt, iż dana osoba złamała normy prawa zawarte $\mathrm{w}$ obowiązujących przepisach karnych, jak również normy moralne funkcjonujące w środowisku jej życia. Ponadto, należy zakładać, iż hierarchia wartości determinująca życiową postawę przestępcy, w tym szczególnie postawę wobec poszanowania norm prawa, została zachwiana. „Zachowania naruszające prawo są ze swej natury zachowaniami sygnalizującymi, że system wartości danej osoby jest zaburzony w stosunku do postulowanego, uznawa-

2 Artykuł 1 ustawy o kuratorach sądowych z 21 lipca 2011 roku - Dz. U. 2001 Nr 98 poz. 1071 - brzmi, „Kuratorzy sądowi realizują określone przez prawo zadania o charakterze wychowawczo-resocjalizacyjnym, diagnostycznym, profilaktycznym i kontrolnym, związane z wykonywaniem orzeczeń sądu”. 
nego, uniwersalnego systemu wartości opartego na powszechnie akceptowanej koncepcji człowieka jako istoty rozumnej, kochającej, wybierającej, wolnej, odpowiedzialnej, której jednocześnie przysługuje godność, szacunek, prawo do wszechstronnego rozwoju”3. Działania kuratora sądowego w wyznaczonym okresie próby zmierzać powinny do konstruowania swoistych postaw aksjologicznych u podopiecznego. Sam zaś dozór kreować powinien płaszczyznę stwarzającą szansę interakcji, sprzyjającej nawiązaniu więzi interpersonalnej jako „czynnika pośredniczącego $\mathrm{w}$ procesie wdrażania skazanego do przestrzegania ładu aksjologicznego społeczeństwa"4.

W niniejszym artykule, w kontekście przybliżonej we wstępie problematyki, stawiam następujące problemy badawcze: Czy istnieje skuteczna, a zarazem moralna strategia działania probacyjnego kuratora sądowego pozwalająca zachować granice wolności wewnętrznej osoby dozorowanej? Czy kompetencje moralne stanowią mandat do podejmowania przez kuratorów sądowych odpowiedzialnych działań readaptacyjnych skazanych w wymiarze aksjologicznym? Czy rola kompetencji moralnych kuratorów sądowych w procesie probacji jest dostrzeżona i uwzględniona przez ustawodawców? Szukając odpowiedzi na postawione pytania w pierwszej kolejności, na podstawie próby rozstrzygnięcia podstawowego dylematu moralnego w probacji, będę starała się wskazać i poddać refleksji komponenty wybranej strategii działań probacyjnych. W dalszej części artykułu jeden ze składników owej strategii działania, a mianowicie kompetencje moralne, zostanie rozwinięty w kontekście wybranych teorii i koncepcji. W ostatniej części artykułu podejmę próbę odszukania elementów kompetencji moralnych w aktach prawnych właściwych dla funkcjonowania polskiej kurateli sądowej.

${ }^{3}$ K. Ostrowska, Aksjologiczno-moralny aspekt kurateli sądowej, Materiały z I Kongresu Kuratorskiego „Dziewięćdziesięciolecie kurateli sądowej w Polsce, Historia - Teraźniejszość - Przyszłość”, Ustka 15-17 czerwca 2009 roku, s. 145.

4 A. Bałandynowicz, Probacja. Resocjalizacja z udziałem społeczeństwa, Warszawa 2006, s. 238. 


\section{Strategia dZiaŁania Probacyjnego W WYMIARZE AKSJOLOGICZNYM}

W działalność probacyjną w wymiarze aksjologicznym wpisanych jest wiele dylematów etycznych, moralnych będących $\mathrm{w}$ korelacji z relacją wolności i odpowiedzialności za słowo. Prawa demokratyczne jednostki implikują akceptację jej autonomicznych sądów wyrażanych na określonych temat, które z różnych przyczyn mogą odbiegać od powszechnych w zbiorowości lokalnej poglądów. „Jednakże sposób wyrażania przez jednostki własnych opinii nie może deprecjonować wartości uznawanych przez pozostałych członków społeczeństwa; podobnie jak działanie osoby posiadającej odmienną hierarchię wartości nie może godzić w prawne chronione dobra zbiorowości. [...] W efekcie znajdujemy się w sytuacji, w której prawo jednej osoby do działania zgodnie z jej zasadami uderza krzywdząco w prawa innych obywateli. Społeczeństwo staje zatem wobec decyzji - czyje wartości powinny zostać objęte ochronną prawną"5. W praktyce kurator sądowy zostaje postawiony przed zasadniczym problemem: Jak pomóc w readaptacji osobie dozorowanej, uwzględniając jej prawo do autonomicznego systemu wartości, jednocześnie przestrzegając norm, zasad i wartości społeczeństwa, w którym ów proces zachodzi? Propozycją rozwiązania postawionego dylematu jest wdrożenie do strategii działań w ramach kurateli sądowej trzech wzajemnie warunkujących się elementów, takich jak: 1) nawiązanie z dozorowanym autentycznej więzi interpersonalnej; 2) sprowadzenie działań probacyjnych do promocji zachowań wyrażających poszanowanie norm prawa; 3) kompetencje moralne kuratorów sądowych.

Poddając refleksji pierwszy z elementów - więź interpersonalną - należy odwołać się do fundamentalnych zasad kształtujących postępowanie metodą indywidualnych przypadków: 1) akceptowanie i respektowanie osoby poddanej kurateli; 2) uznawanie jej prawa do

5 Tenże, Doświadczenia Polski i innych krajów Europy Zachodniej dotyczące odpowiedzialności społeczności lokalnych za działalność probacyjną, „Probacja” 2011, nr 1, s. 84. 
samostanowienia o sobie; 3) uświadomienie niezbędności czynnego i kompetentnego współuczestnictwa w rozwiązywaniu problemów życiowych skazanego. W tak zarysowanej przestrzeni kurator ma możliwość nawiązać autentyczną więź z dozorowanym, która to staje się mandatem do działań probacyjnych w wymiarze aksjologicznym. „Zakres wywieranego wpływu przez kuratora na osobę poddaną kurateli określa jakość związku, więzi nawiązywanych w toku wspólnego rozwiązywania problemów życiowych więźnia".

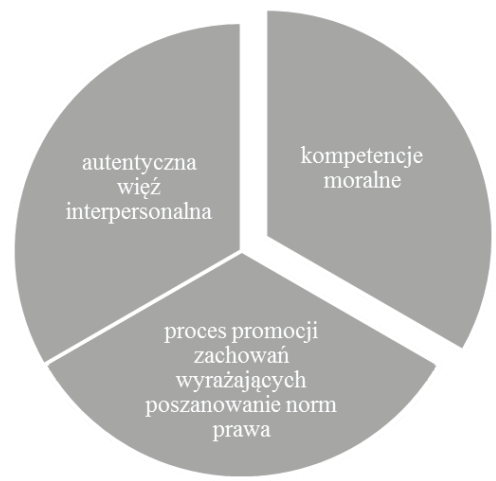

Ryc. 1. Strategia działań w ramach kurateli sądowej

Źródło: koncepcja własna.

Zdaniem Katarzyny Jadach posługiwanie się metodami pracy resocjalizującej bazującej na zależnościach wewnętrznych jest szczególnie cenne z dwóch powodów: po pierwsze, gwarantują realną silną więź pomiędzy jednostką niedostosowaną społecznie a osobą dozorującego; po drugie, dają w związku z tym szansę na uzyskanie trwałej wewnętrznej przemiany u podopiecznego, wyrażającej się przewartościowaniem jego systemu aksjologicznego oraz przyjęciem pożąda-

6 Tamże, s. 91. 
nych postaw umożliwiających konstruktywne pełnienie nałożonych przez społeczeństwo ról”"

Nawiązaniu więzi interpersonalnej z dozorowanym sprzyja sprowadzenie działań probacyjnych w wymiarze aksjologicznym do promocji zachowań wyrażających poszanowanie norm prawa obowiązujących w społeczeństwie. „Tak jak współczesna medycyna, podkreślająca wagę dbania o zdrowie jako sposób zapobiegania chorobom, tak i probacja kładzie nacisk na zapobieganie zachowaniom niezgodnym z prawem poprzez promocję zachowań zgodnych z prawem. Faworyzując resocjalizację zamiast więzienia, probacja chroni społeczeństwo i jednocześnie zapobiega zbrodniom"8. Promocja taka, zdaniem Krystyny Ostrowskiej, powinna być oparta na wiedzy i rozumnej akceptacji systemu wartości, który gwarantuje kształtowanie pozytywnych postaw wobec poszanowania prawa. Innymi słowy, chodzi o posiadanie przez kuratora nijako matrycy wartości, które w kontaktach z podopiecznym chce się uwyraźniać, do których chce się go zachęcać, aby przyjął, zinternalizował i urzeczywistniał ${ }^{9}$. Dlaczego działania probacyjne w wymiarze aksjologicznym powinny przyjąć postać promocji i to promocji zawężonej grupy zachowań? Prawo do autonomicznego systemu wartości dozorowanego stawia przed kuratorem moralną granicę oddziaływań. Ponadto należy podkreślić, iż osobowość podopiecznego jest już zasadniczo ukształtowana. Transformacja zupełnie nowej jakości aksjologicznej zakotwiczona jest w sferze deklaratywnej. Jednakże to, co stanowi mianownik zachowań przestępczych, to fakt, iż sygnalizują, że wartości związane z poszanowaniem norm prawa zostały zdegradowane. Z tego względu wspomniana promocja wartości w relacji kuratora sądowego z podopiecznym w ramach aksjologicznego wymiaru probacji powinna dotyczyć szczególnie wartości kształtujących zachowania wyrażające szacunek i poważanie wobec prawa oraz zgodne $\mathrm{z}$ nim działanie. Poszanowanie norm prawa jest warunkiem

7 K. Jadach, Praca kuratora sadowego $w$ sprawach rodzinnych, nieletnich i karnych, Poznań 2011, s. 55.

8 A. Bałandynowicz, Probacja - wielopasmowa teoria resocjalizacji i udziałem społeczeństwa, „Probacja” 2009, nr 1, s. 24.

9 K. Ostrowska, Aksjologiczno-moralny aspekt kurateli sądowej..., s. 143. 
koniecznym i wystarczającym do przyjęcia pewnego minimum aksjologicznego wymaganego przez społeczeństwo od jednostki w procesie jej readaptacji. Ponadto, pomimo zawężenia oddziaływań kuratora $\mathrm{w}$ toku interakcji do promocji zachowań wyrażających poszanowanie norm prawa, niewykluczone jest, iż jednocześnie nastąpi uwrażliwienie podopiecznych na całą pulę ważnych społecznie wartości.

Kompetencje moralne kuratorów sądowych stanowią element scalający i warunkujący urzeczywistnianie wskazanej strategii działania. Od ich poziomu bowiem zależna jest pomyślność nawiązania autentycznej więzi z podopiecznym oraz efektywność realizacji procesu resocjalizacji sprowadzonego do promocji wybranych zachowań. Kompetencje moralne uznać należy także za kluczowe w relacji wolności i odpowiedzialności za słowa w kontekście etyki zawodowej. Stanowią one przedmiot refleksji wielu teorii, koncepcji. Przybliżenie kontekstu wybranych pozwoli na zdefiniowanie zakresu znaczeniowego tego terminu oraz wskazanie tych niezbędnych elementów do kompetentnego zachowania się kuratora sądowego dla dorosłych w zarysowanym polu działania.

\section{KOMPETENCJE MORALNE W UJĘCIU WYBRANYCH TEORII}

Robert Kwaśnica, poddając refleksji swoistość zawodu nauczyciela, wyodrębnił i scharakteryzował rozważane kompetencje moralne. Autor, spełniając wskazane przez siebie warunki opisu szczegółowych kompetencji wybranej grupy zawodowej (wybiórczość i założeniowość), za podstawę swoich rozważań przyjął koncepcje dwóch racjonalności ${ }^{10}$. Wedle tej koncepcji doświadczenie ludzkie tworzy się w dwóch sferach znaczeń: w obszarze wiedzy praktyczno-moralnej i w obszarze wiedzy technicznej. Wiedza praktyczno-moralna to ten rodzaj doświadczenia, które nabywamy w praktyce komunikacyjnej, w szeroko pojętym dialogu, i które daje znać o sobie w trojaki sposób. Po pierwsze, zdaniem autora, z niego czerpiemy całościowe wi-

10 R. Kwaśnica, Dwie racjonalności. Od filozofii sensu ku pedagogice ogólnej, Wrocław 1987. 
zje świata, dzięki którym potrafimy odróżnić to, co dla nas (w ramach wspólnoty komunikacyjnej, do której należymy) ma moc zobowiązującą, od tego, co nie mieści się w zaakceptowanym przez nas porządku. Po drugie, charakteryzowana wiedza określa reguły stanowienia sensu i dostarcza zasad moralnych ustalających nasz stosunek do siebie samych i do innych ludzi oraz normuje nasze postępowanie. Po trzecie, wiedza ta umożliwia dialogowe porozumiewanie się z innymi, co sprzyja poddawaniu jej rewizji i krytyce, a także zobowiązuje do przestrzegania etyki mowy. Etyka ta umożliwia uczestnikom komunikacji równe uprawnienia i nakłada na nich wspólny obowiązek znoszenia blokad komunikacyjnych powodowanych przez stosunki panowania, podległości i przemocy. Wiedza techniczna natomiast jest doświadczeniem ukazującym świat (rzeczy innych ludzi i nas samych) jako przedmiot naszych sprawczych oddziaływań. Wiedza ta okazuje się użyteczna w trojaki sposób: po pierwsze - wskazuje cele, które należy osiągnąć, po drugie - dostarcza wiadomości o metodach pomocnych w ich realizacji, po trzecie - określa środki i warunki, od których zależy możliwość osiągnięcia celów, czy inaczej - od których zależy możliwość skutecznego posługiwania się metodami ${ }^{11}$.

Na podstawie przybliżonej koncepcji ludzkiego doświadczania Robert Kwaśnica wyodrębnił dwie grupy kompetencji: zajmującą nadrzędną pozycję kompetencje praktyczno-moralne oraz techniczne. W pierwszej grupie rozróżnił kompetencje interpretacyjne, moralne oraz komunikacyjne, w drugiej zaś postulacyjne, metodyczne oraz realizacyjne. Na podstawie własnych rozważań zdefiniował kompetencje moralne, które według autora - „nie są - mimo pozorów, tym samym, co wiedza o normach i nakazach moralnych. Są natomiast zdolnością prowadzenia refleksji moralnej. Ich udział w naszym życiu wyraża się w pytaniach o prawomocność moralną naszego postępowania. W zależności od poziomu rozwoju moralnego pytania te zadajemy inaczej, różnie też na nie odpowiadamy, ale domagają się one wciąż tego samego - namysłu na moralną prawomocnością własnych zachowań. A za-

11 Tenże, Być nauczycielem - wprowadzenie do myślenia, w: Pedagogika. Podręcznik akademicki, t. 2, pod red. Z. Kwiecińskiego, B. Śliwerskiego, Warszawa 2003, s. 299. 
tem refleksja, którą umożliwiają kompetencje moralne, jest zawsze autorefleksją, jest samorozumieniem wzbudzanym i podtrzymywanym wciąż przez to samo pytanie: jaki powinien być i w jaki sposób powinien postępować, by z jednej strony dochować wierności sobie i nie ulec duchowemu zniewoleniu, a drugiej - by swym postępowaniem nie ograniczać innych ludzi w ich prawach do wewnętrznej wolności i podmiotowości i w prawie do wyboru własnej drogi?"12.

Zatem za jeden z komponentów kompetencji moralnych można uznać zdolność do refleksji moralnej, którą autor powiązał z uzyskanym przez człowieka poziomem rozwoju moralnego. Co ciekawe, Lawrence Kohlberg, twórca jednej z najbardziej znaczących teorii moralnego rozwoju, kompetencji moralnych nie powiązał ze zdolnością do refleksji, a ze „zdolnością do podejmowania decyzji i ocen, które są moralne i działania zgodnie z nimi"13. Jednym z centralnych i zarazem dyskusyjnych założeń wskazanej teorii jest założenie uniwersalizmu. Uniwersalizm moralny Lawrenca Kohlberga wyraża się w dwóch szczegółowych twierdzeniach. Zgodnie z pierwszym twierdzeniem zasady moralne są uniwersalne i we wszystkich kulturach spotykamy te same kategorie sądów moralnych, które koncentrują się wokół zasad sprawiedliwości. Opisując najwyższy poziom rozwoju moralnego (uwzględniając jego sekwencyjność), Lawrence Kohlberg również odwołał się to tej tezy. Uznał bowiem, iż rozwój polega na przechodzeniu od sądów, przekonań i zasad postępowania, uwzględniających jedynie własną perspektywę jednostki, do ogólnych uniwersalnych reguł, które odnoszą się do wszystkich ludzi i wszystkich sytuacji. W myśl drugiego twierdzenia rozwój moralny przebiega w sposób niezmienny w określonym porządku sekwencyjnym we wszystkich kulturach. Tym, co różni poszczególne jednostki, jest tempo owego rozwoju oraz najwyższe osiągnięte stadium ${ }^{14}$. Poprzez sekwencyjność rozwoju autor wykazuje, iż wyższe stadium jest obiektywnie lepsze niż niższe, nie

12 R. Kwaśnica, Być nauczycielem..., s. 300.

13 C. Hendryk, O zagubionych kompetencjach moralnych,, „General and Professional Education" 2010, nr 1, Szczecin, s. 134.

14 D. Czyżkowska, O celu i granicach rozwoju moralnego, „Analiza i Egzystencja" 2008, nr 8, s. 86. 
tylko dlatego, że jest bardziej wartościowe moralnie, ale również dlatego, iż umożliwia formułowanie bardziej słusznych i moralnie właściwych sądów. Jego wyższość jest natury poznawczej oraz moralnej ${ }^{15}$.

W myśl teorii rozwoju moralnego, orientacja moralna jednostki jest konsekwencją jej rozwoju poznawczego. Obecnie jednak coraz większa uwaga uczonych jest poświęcana roli emocji w moralnym rozwoju człowieka ${ }^{16}$. Georg Lind rozwinął niezależną, popartą wieloma eksperymentami teorię dwóch aspektów moralności (dual aspect theory of morality). Według autora, koncentrując się na teoriach poznawczo-rozwojowych, dostrzegamy tylko poznawczy, a pomijamy afektywny aspekt rozwoju moralnego. „Tymczasem musimy zdawać sobie sprawę z faktu, że aspekt afektywny nie jest dla kompetencji moralnych drugorzędny lub mniej waży. Kompetencje moralne oznaczają zarówno chęć oparcia swojego zachowania na uniwersalnych moralnie maksymach, jak również zdolność do spójnego stosowania tych zasad w jednym zachowaniu, czyli na przykład do oceny działania zgodnie z zasadami moralnymi, nawet jeśli jest to sprzeczne z wcześniejszymi własnymi nawykami i opiniami"17. Na ważność związku aspektu afektywnego z rozwojem moralnym zwrócił uwagę również Martin Hoffman. W swojej teorii utrzymuje, iż „empatia - sama lub w połączeniu z zasadą moralną - może odgrywać istotną rolę w osądzie moralnym. Jeśli odczuwamy empatię wobec innych ludzi, to zwykle pochwalamy działania sprzyjające ich dobru i potępiamy te, które mogą wyrządzić im krzywdę. Empatia może wpływać na osąd moralny dotyczący nas samych lub innej osoby bezpośrednio lub pośrednio, poprzez zasady moralne, które uaktywnia"18.

Za integralnym modelem kompetencji moralnej, uwzględniającym między innymi komponent emocjonalny, opowiada się James Liszka. W swych rozważaniach kompetencję moralną ujmuje jako zbiór wza-

15 Tamże, s. 88.

16 C. Hendryk, O zagubionych kompetencjach..., s. 134.

17 G. Lind, Moral competence and education in a democratic society, Reidel Publications 1987, s. 91-122, w: C. Hendryk, O zagubionych kompetencjach..., s. 135.

18 M. Hoffman, Empatia i rozwój moralny, Gdańsk 2006, s. 25, w: C. Hendryk, O zagubionych kompetencjach..., s. 136. 
jemnie powiązanych ze sobą ważnych zdolności: uczuć moralnych, pragnienia słusznych rzeczy, siły moralnej oraz mocy (sprawstwa) do jej urzeczywistniania, prawości (cnoty) i umiejętności jej stałego dochowania, mądrości i umiejętności jej zdobycia, wiedzy, czym jest robienie odpowiednich (słusznych) rzeczy ${ }^{19}$. Autor, poddając refleksji wskazane komponenty, podkreśla ich niehierarchiczność. W myśl jego teorii do powszechnych emocji moralnych zalicza poczucie winy, wstyd, podziw, wstręt, wyrzuty sumienia, żal (ubolewanie) oraz sympatię. Emocje te stanowią integralną część życia, wpływają na stosunek do siebie i innych ${ }^{20}$. Kolejny element - siłę woli - James Liszka łączy z autonomią. Siła woli umożliwia skupienie się na wykonywaniu zadania, pokonaniu zmęczenia czy zniechęcenia oraz oparcia się pokusie. Autonomia obejmuje panowanie nad sobą, samosterowność, opanowanie, własną skuteczność (zdolność pokonywania przeszkód i znoszenia cierpienia $\mathrm{w}$ imię jakiegoś celu) ${ }^{21}$. Równie istotnym elementem kompetencji moralnej jest cnota, którą autor identyfikował z samokontrolą, własną skutecznością, szacunkiem i z życzliwością ${ }^{22}$. Omawiając mądrość, James Liszka nawiązuje między innymi do koncepcji Roberta J. Stenberga, zgodnie z którą człowiek mądry posiada unikalną zdolność, aby spojrzeć na problem lub sytuację i rozwiązać go w zadowalający moralnie sposób. Wskazując na strukturę mądrości, wymienia w niej wyobraźnię (wizję), która odnosi się do końca działania i obejmuje zrozumienie moralnego porządku świata, dobro wspólne i dobre życie. Mądrość zawiera w sobie także rozwagę i słuszny osąd ${ }^{23}$. Odnosząc się do wiedzy moralnej, przytacza etapy rozumowania moralnego (moral reasoning) w ujęciu Lawrence Kohlberga i Carol Gilligan. Wyróżnia także następujące etapy (poziomy) wiedzy moralnej (moral knowledge): 1) klaryfikacja (identyfikacja ukrytych

19 J. J. Liszka, Moral Competence: An Integrated Approach to the Study of Ethics, New Jersey 2002, s. 18, w: C. Hendryk, O zagubionych kompetencjach..., s. 136.

20 J. J. Liszka, Moral Competence..., s. 17.

21 Tamże, s. 80-136.

22 Tamże, s. 141-200.

23 Tamże, s. 218-219. 
reguł moralnych); 2) systematyzacja (kodyfikacja zasad moralnych); 3) uzasadnienie (ustanowienie kodu moralnego) ${ }^{24}$.

Ujmując kompetencje moralne $\mathrm{w}$ postaci zbioru zdolności - jako niezmiernie istotną dla rozumnego otwarcia się na wartości i zgodnego z nimi postępowania - należy uznać wrażliwość aksjologiczną, definiowaną jako „zdolność człowieka do wartościowania wrażeń pochodzących ze świata zewnętrznego lub/i ze świata wewnętrznego organizmu oraz do internalizowania systemu wartości i ich hierarchii jako podstawy postępowania podmiotu"25. Termin ten wprowadziła Urszula Ostrowska, jako pojęcie szersze od funkcjonującego w piśmiennictwie określenia „wrażliwość moralna” definiowana jako „swoista dyspozycja człowieka przejawiająca się w wyczuleniu na niesprawiedliwość i krzywdę, niesieniu pomocy słabszym i potrzebującym”26. „Wrażliwość człowieka uwikłanego w sieci antroposferycznej dotyczy bowiem nie tylko jakichś wyizolowanych fragmentów, lecz w zależności od poziomu wrażliwości aksjologicznej, jaki reprezentuje, bądź do którego aspiruje podmiot - może ona przybrać różną siłę, moc oraz zakres" 27 . Na podstawie przeprowadzonych badań i towarzyszącym im rozważań autorka rozróżniła cztery poziomy wrażliwości aksjologicznej: 1) brak wrażliwości aksjologicznej - atrofia aksjologiczna; 2) wrażliwość aksjologiczna zawężona/zaniżona/częściowa; 3) właściwa wrażliwość aksjologiczna; 3a) podwyższona wrażliwość aksjologiczna; 4) nadwrażliwość aksjologiczna. Z uwagi na kontekst rozważań najbardziej pożądanym poziomem wrażliwości aksjologicznej wydaje się być poziom trzeci, „właściwa wrażliwość aksjologiczna”, i jego subpoziom (3a) „podwyższona wrażliwość aksjologiczna”. Urszula Ostrowska zaznacza jednak, iż granice między poziomami są subtelne, płynne, trudno uchwytne. Osiągnięcie danego poziomu

24 Tamże' s. 322-324.

25 U. Ostrowska, Aksjologiczne podstawy wychowania, s. 409, w: Pedagogika. Podstawy nauki o wychowaniu, Podręcznik akademicki, t. 1, pod red. B. Śliwerskiego, Gdańsk 2006.

${ }^{26}$ Mały słownik etyczny, pod. red. S. Jedynaka, Bydgoszcz 1994, s. 249, w: U. Ostrowska, Doświadczanie wartości edukacyjnych w szkole wyższej, Bydgoszcz 1998, s. 58.

27 U. Ostrowska, Doświadczanie wartości edukacyjnych..., s. 58-59. 
wrażliwości nie jest stałe, może ono ulec zmianie w obu kierunkach (z wyjątkiem dwóch skrajnych, gdzie kierunek zmian jest jednokierunkowy). W zawodach, do grupy których niewątpliwie wpisuje się kurator sądowy, którym towarzyszy ciągła ekspozycja na krzywdę ludzką i niejednokrotnie towarzysząca jej niemoc sprawcza w kierunku jej poprawy, pojawia się częstokroć syndrom wypalenia zawodowego, który w swojej naturze może prowadzić do zawężonej/zaniżonej bądź częściowej wrażliwości aksjologicznej bądź do atrofii w tej sferze. „Toteż może okazać się nieodzowną permanentna - jak to określa autorka [przyp. - K. G.] - »czujność aksjologiczna« osób w tym zakresie, zwłaszcza na obszarach »przygranicznych« zaprezentowanych powyżej poziomów, aby wystrzegać się ewentualności zarówno »niedomiaru«, jak i chorobliwie wynaturzonego »nadmiaru« wrażliwości aksjologicznej"28.

Reasumując przytoczone stanowiska, kompetencje moralne stanowią swoisty zbiór predyspozycji (wrażliwość aksjologiczna, empatia) i zdolności, którym przewodzi zdolność prowadzenia refleksji moralnej, wyrażana w życiu człowieka w pytaniach o moralną prawomocność postępowania. Ponadto istotna jest wiedza o uniwersalnych normach, nakazach moralnych i wartościach towarzyszących współcześnie funkcjonującym społeczeństwom, których podstawę stanowi praworządność. Zaznaczając, iż sama wiedza nie stanowi autonomicznego komponentu kompetencji moralnych, ale ich dopełnienie. Robert Kwaśnica podkreśla, iż kompetencja moralna nie polega oczywiście tylko na refleksji, lecz jest widoczna w konkretnym działaniu moralnym. Cechy takie jak moralna wrażliwość, zdolność oceny byłby bezskuteczne, gdyby ograniczały się do czucia, myślenia i mówienia o moralności. Kompetencja moralna udowadnia się w działaniu ${ }^{29}$. Prawidłowość ta stanowi podstawę rozważań dotyczących kompetencji moralnych kuratorów sądowych dla dorosłych. Kurator postawiony w obliczu sytuacji trudnej - dylematu moralnego - mający

28 Taż, Aksjologiczne podstawy..., s. 60.

29 R. Kwaśnica, Wprowadzenie do myślenia o wspomaganiu nauczycieli $w$ rozwoju, „Studia Pedagogiczne”, t. LX, Warszawa 1995, s. 20-21, w: C. Hendryk, O zagubionych kompetencjach..., s. 138. 
świadomość konsekwencji i odpowiedzialności za swoje decyzje podejmowane na podstawie własnego osądu moralnego, zgodnie z własnym sumieniem, powinien bowiem podjąć działanie zmierzające do jego rozwiązania. Ponadto zobowiązany jest brać pod uwagę fakt, iż następstwo jego decyzji dotyka przede wszystkim osoby będącej pod jego pieczą. Mając na względzie unifikację działań w sytuacjach moralnie trudnych i zawiłych, skonstruowano kodeks etyki dla tej grupy zawodowej. Zawarte w nim normy moralne wskazywać mają kierunek i cel prowadzonej działalności, a w sytuacji konieczności zmierzenia się z dylematem moralnym - pomagać w jego rozstrzygnięciu.

\section{KLUCZOWE KOMPETENCJE KURATORÓW SĄDOWYCH W ASPEKCIE PRAWNYM}

Kurator sądowy dla dorosłych podejmujący próbę readaptacji skazanego do środowiska jego życia powinien legitymować się szczególnymi kompetencjami zawodowymi sprzyjającymi prowadzeniu skutecznej metodyki pracy resocjalizacyjnej. Jednakże czy kompetencje moralne są uwzględnione w wymaganiach dla kandydatów ubiegających się na tę funkcję? Ustawodawca precyzyjnie sformułował wymagania formalne ${ }^{30}$, z jednym wyjątkiem. Artykuł 5.1 punkt 2 ustawy ${ }^{31}$ brzmi, iż „Kuratorem zawodowym może być mianowany ten, kto jest nieskazitelnego charakteru". Wymóg ten sformułowany lapidarnie nie został opatrzony ustawowym komentarzem, umożliwiając tym samym wieloaspektową interpretację. W okresie międzywojennym Sąd Najwyższy podjął próbę zdefiniowania tego pojęcia, stwierdzając, że „przez osoby nieskazitelnego charakteru rozumieć należy osoby nie tylko niekarane za czyny hańbiące lub antyspołeczne, lecz posiadające po-

30 Kuratorem zawodowym może być mianowany ten, kto posiada obywatelstwo polskie i korzysta w pełni z praw cywilnych i obywatelskich, posiada wyższe specjalistyczne wykształcenie, jest zdolny ze względu na stan zdrowia do pełnienia obowiązków kuratora oraz odbył aplikację kuratorską zakończoną egzaminem - art. 5.1 u.o.k.s.

31 Ustawa o kuratorach sądowych z 21 lipca 2011 roku - Dz. U. 2001 Nr 98 poz. 1071. 
nadto kwalifikacje etyczne nieprzeciętne, bo niedopuszczające skazy, nawet takiej, którą ogół zwykł traktować pobłażliwie"32. Współcześnie pojęcie „nieskazitelnego charakteru” należy, zdaniem Katarzyny Gromek, tłumaczyć dynamicznie, w sposób ekstensywny, dążąc raczej do skatalogowania cech, tworzących paradygmat kuratora, niż podejmując wysiłek w celu objaśnienia wyrażeń „nieskazitelny” oraz „charakter" 33 . Zatem kandydat na kuratora sądowego powinien być uczciwy, pracowity, nieposzlakowany, zrównoważony, sumienny, odważny, cierpliwy, o wysokiej kulturze osobistej, bystry, uprzejmy, samokrytyczny, otwarty intelektualnie oraz obdarzony wewnętrznym poczuciem niezależności. Powinien jasno wyrażać swoje myśli, rozumować dyskursywnie, dobrze pisać, być wrażliwy, ale zarazem surowy i rygorystyczny w stosowaniu przepisów oraz mieć wysokie poczucie sprawiedliwości i słuszności, z jednoczesną skłonnością do rozumnego kompromisu ${ }^{34}$. „Prócz tego powinniśmy wymagać od niego, aby był wolny od uzależnień, nie powinien wchodzić w konflikty i nie powinien być zgorszeniem dla innych, winien natomiast wieść przykładny tryb życia. Powinny go również cechować: empatia, altruizm, zaangażowanie, życiowy optymizm, zaufanie do ludzi czy troska o innych"35. Niektórzy autorzy podkreślają również, że kandydat na kuratora sądowego powinien mieć unormowaną sytuację osobistą i rodzinną ${ }^{36}$.

Wymienione interpretacje pojęcia „nieskazitelny charakter”, choć dotykające swoim zakresem istotnych komponentów determinujących sprawność w działaniach probacyjnych kuratora sądowego w środowisku życia podopiecznego, nie zawierają bądź nie dookreślają wprost istotnych w świetle podejmowanej problematyki kompetencji refleksyjnego namysłu nad artykułowanymi w relacji z dozorowanym sło-

32 Postanowienie z dnia 18 stycznia 1933 roku, II K.Adw. 7/2, w: K. Gromek, Kuratorzy sądowi. Komentarz, Warszawa 2005, s. 61.

33 K. Gromek, Kuratorzy sądowi. Komentarz, Warszawa 2005, s. 61.

34 Tamże, s. 62.

35 T. Jedynak, K. Stasiak, Komentarz do ustawy o kuratorach sądowych, Warszawa 2008, s. 68, w: Kodeks Etyki Kuratora Sądowego - od kwalifikacji moralnych do kompetencji etycznych, A. Samek „Probacja” 2013, nr 2, s. 132.

${ }^{36}$ Komentarz do prawa o ustroju sądów powszechnych i ustawy o Krajowej Radzie Sądownictwa, pod red. J. Gudowskiego, Warszawa 2002, s. 167-168. 
wami i ich konsekwencjami w wymiarze wolności. Przyjmując, iż proces probacji zmierza do konstruowania kompetencji aksjologicznych u skazanych, nieuniknione jest wywieranie wpływu na tożsamość skazanego, co z kolei wiąże się z zagrożeniem ograniczania wolności wewnętrznej. Nieskazitelny charakter kuratora sądowego w świetle aksjologicznego wymiaru probacji powinien być zatem tożsamy z kompetencjami moralnymi. Moralność bowiem nierozerwalnie związana jest odpowiedzialnością, a ta stanowi atrybut wielu profesji, od osądu których zależne są losy ludzi podlegających ich opiece. Dlaczego więc w interpretacjach „nieskazitelnego charakteru” trudno się doszukać tychże ani pod właściwą nazwą, ani pod określeniami pokrewnymi takimi jak kompetencje etyczne, kompetencje społeczno-moralne? Uzasadnienia takiego stanu rzeczy można uzyskać, odnosząc się do odgórnego wzoru, jaki stanowią Europejskie Ramy Kwalifikacji. Kompetencje moralne nie zostały tu uwzględnione, ponieważ uznaje się je za kompetencje bardziej ogólne, a nawet za metakompetencje. „Te cechy, często zwane metakompetencjami, nie zostały włączone, gdyż nie mogą być postrzegane niezależnie od reszty wiedzy, umiejętności i kompetencji. Dlatego też nie zostały dorzucone jako dodatkowe wymiary, ale powinny być postrzegane jako integralna część wiedzy, umiejętności i kompetencji" ${ }^{37}$. Zdaniem Cezarego Hendryka nie jest ławo zgodzić się z taką argumentacją. Jeżeli uznać kompetencje moralne za metakompetencje, to zasługują one na szczególne zaznaczenie, a nie pominięcie, gdyż przedrostek „meta” czyni z nich specyficzny rodzaj kompetencji związany z umiejętnością samorefleksji dotyczących posiadanych kompetencji, możliwości ich rozwoju. Zdaniem autora wszystkie rodzaje kompetencji przenikają się wzajemnie, przy czym metakompetencje w sposób szczególny wpływają na pozostałe, stanowiąc podstawę ich rozwoju ${ }^{38}$.

37 Od Europejskich do Krajowych Ram Kwalifikacji, pod red. E. Chmieleckiej, Warszawa 2009, s. 67, w: C. Hendryk, O zagubionych kompetencjach. Kompetencje moralne, „General and Professional Education” 2010, nr 1, Szczecin, s. 132.

38 C. Hendryk, O zagubionych kompetencjach..., s. 132. 


\section{Podsumowanie}

Działalność probacyjna, szczególnie w wymiarze aksjologicznym, narażona jest na zagrożenie przekroczenia już zachwianej granicy wolności osobowej dozorowanego. Formalna asymetria relacji funkcjonariusza publicznego z podopiecznym, jak i płaszczyzna dozoru obwarowana szeregiem ograniczeń implikują potrzebę moralnej refleksji w interakcji werbalnej ze strony kuratora sądowego. Kluczowego znaczenia $\mathrm{w}$ procesie promocji zachowań wyrażających poszanowanie norm prawa nabierają kompetencje zawodowe kuratorów, w tym szczególnie kompetencje moralne (nieskazitelny charakter). Stanowią one mandat do nawiązania głębszej, podmiotowej relacji kuratora sądowego z podopiecznym, a tym samym do przewartościowania jego systemu aksjologicznego, co wpisuje się w docelowe budowanie tożsamości osobowej skazanego. Wysoki poziom kompetencji moralnych pozwala kuratorowi niwelować bezrefleksyjne ingerowanie w wolność wewnętrzną podopiecznego, a także, co istotne, umożliwia jej kształtowanie. Andrzej Bałandynowicz, poddając refleksji proces reintegracji skazanego w środowisku jego życia w aspekcie aksjologicznym, akcentował bowiem, iż „kształtowanie wolności wewnętrznej sprawcy przestępstw należy do najistotniejszych celów resocjalizacji, bowiem tylko jednostka, która będzie dysponowała zintegrowaną osobowością, może być włączona do świata wolnego"39.

Wartość statutową wszelkich działań systemowych, w tym resocjalizacyjnych, stanowi etyka. Kodeksy deontologiczne unifikują kierunek działań i funkcjonują jak kompas w sytuacji trudnej etycznie. Ponadto stanowią istotny element wpływający na poziom kompetencji moralnych, tuż obok poziomu dojrzałości moralnej i wrażliwości aksjologicznej, motywacji do działań prospołecznych i wewnętrznego sytemu wartości.

39 A. Bałandynowicz, Reintegracja społeczna skazanych wsparta na paradygmacie tożsamości osobowej, społecznej i kulturowo-cywilizacyjnej, „Probacja” 2011, nr 4, s. 68, cyt. za: B. Wojcieszke, Struktura „Ja”, wartości osobiste i zachowania, Wrocław 1986. 
Jakim poziomem kompetencji moralnych legitymują się sądowi kuratorzy dla dorosłych, pełniący służbę w polskich sądach rejonowych? Odpowiedzi na postawione pytanie można szukać w przekonaniach Iji Lazari-Pawłowskiej stanowiących, iż „kodeksy etyk zawodowych byłyby zbędne, gdyby ludzi poszczególnych zawodów charakteryzował wysoki poziom moralny, wrażliwość i niezawodnie dobra wola. Nie twierdzi ona, że sformułowany zbiór zasad obowiązujących daną grupę zawodową ostatecznie wyznacza poziom moralny tej grupy, lecz że znacznie na niego wpływa"40.

\section{Summary}

MORAL COMPETENCE IN PROBATION AS A CRUCIAL ELEMENT IN THE CONTEXT OF FREEDOM AND RESPONSIBILITY FOR WORDS

The asymmetry in the probation relationship implies necessity of discretion and responsibility for words from probation officers. For this reason, principles of effective resocialization and specialized skills ought to be integrated into community supervision. The crucial components in this context are moral competencies defined by the interdependence of the elements that constitute good moral behavior like: ability to moral reflection, empathy, axiological sensitivity and knowledge of universal norm and moral demands. Employing this kind of competencies enables to preserve offenders' personal freedom, which is a basic condition for adaptation of probationers to a "free society".

40 M. Olech, Ija Lazari-Pawłowska w obronie etyki zawodowej, „Słupskie Studia Filozoficzne", nr 5, Słupsk 2005, s. 76. 